\title{
Assessment of Surface Water Quality around Dumpsites in the City of Ibadan Metropolis, Oyo State, Nigeria
}

\author{
S. Y. Aboho \& B. A. Anhwange \\ Department of Chemistry, Benue State University, Makurdi, Nigeria \\ P. C. Onianwa \\ Department of Chemistry, University of Ibadan, Ibadan, Nigeria \\ E. O. Ekanem \\ Chemistry Programme, Abubakar Tafawa Balewa University, Bauchi
}

Received: May 16, 2011

doi:10.5539/ijc.v4n1p39
Accepted: June 9, $2011 \quad$ Published: February 1, 2012

URL: http://dx.doi.org/10.5539/ijc.v4n1p39

\begin{abstract}
The quality of surface water around Ring road and Orita-Aperin dumpsites were assessed for a period of one year (June 2005 to May 2009) using standards methods of analysis. The following parameters: temperature, turbidity, total dissolves solids (TDS), conductivity, hardness, nitrates, sulphates and ammonia were determined. The mean values per sampling point were temperature $\left(28.40{ }^{\circ} \mathrm{C}\right), \mathrm{pH}(7.20)$, total hardness $\left(87.00 \mathrm{mgCaCO}_{3} \cdot \mathrm{L}^{-1}\right.$ nitrate $\left(11.44 \mathrm{mg} \cdot \mathrm{L}^{-1}\right)$ ammonia $\left(0.12 \mathrm{mg} \cdot \mathrm{L}^{-1}\right)$, sulphate $\left(7.2 \mathrm{mg} \cdot \mathrm{L}^{-1}\right)$, turbidity $(431 \mathrm{FTU})$, total dissolved solids (365 $\left.\mathrm{mg} \cdot \mathrm{L}^{-1}\right)$ and conductivity $\left(47.00 \mathrm{mS} \cdot \mathrm{m}^{-2} \cdot \mathrm{mol}^{-1)}\right.$ for Ring road were not significantly different from those at Orita-Aperin and the other dumpsites. Also, mean values per samples of the same parameters from Agbowo control sites did not differ significantly from those at Ring road, the main dumpsites with the exception of their relatively, high $\mathrm{pH}$, nitrate, ammonia and TDS values. The results were found to compare favourably with WHO and Nigerian Federal Environmental Protection Agency (FEPA) limits, exception of turbidity. The study has revealed that surface water quality around the dumpsites has not been severely impacted as is usually assumed, even though it has been polluted to some degree.
\end{abstract}

Keywords: Assessment, Water quality, Solid waste, Dumpsites, Parameters, Ibadan, Nigeria

\section{Introduction}

Solid wastes have been defined as those solid materials arising from animal or human activities and discarded permanently or temporarily as wastes (Korte \& Bienkiek, 1987). On the basis of sources, solid wastes have been variously classified as domestic, residential, commercial, municipal, industrial and agricultural (Douglas \& Jackson, 1972; Jorgenson \& Johnson, 1989).

Solid waste disposal is the removal of the wastes from human environment so as to avoid the nuisance and health problems associated with such wastes. Proper disposal of these wastes could provide an aesthetically pleasing environment for Man and animals (US. - EPA, 1971). Recently, so much solid waste is being generated that disposal has become a major problem in many urban cities especially in Nigeria. Attempts by the various levels of Government's in solving this problem have not yielded any positive results since over $80 \%$ of the budget allocated for waste management is being spent on waste collection alone, leaving only $20 \%$ for actual disposal, which is most often grossly inadequate (Hughes, London, \& Farvolden, 1971). Solid waste disposal problem is mainly acute in urban areas, characterized by high population density and intense competition for land for various uses. Thus allocation of land for waste disposal is extremely very difficult in most urban cities. Usually, the existing sites get filled up rapidly, resulting to the overflow of disposal sites, which eventually are being flushed by run-off water into the surrounding overflow sources. The introduction of these wastes contaminates the water sources making them unfit for intending purposes. This study was designed to assess the quality of water around two major waste dumpsites in Ibadan metropolis in order to ascertain the levels of contamination of the water sources by these dumpsites. The study will provide information on the inherent health risk if the contamination is beyond 
threshold limits.

\section{Materials and Methods}

\subsection{Sample site selection/sample collection}

The Ring road and Orita-Aperin dumpsites served as sampling /study sites while Agbowo was chosen as the control area. Two sampling points corresponding to up steam and down stream points were selected of the stream/river in each of the study areas. The dump in each case lies between or beside these points. Water samples were collected once every month over a period of one year, using clean plastic containers.

Two sampling points along the stream in Agbowo control area were similarly selected and samples taken. Surface water samples were collected by dipping a clean plastic container perpendicularly into the stream at the selected sample points and water allowed to flow freely into the container.

\subsection{Determinations}

The following parameters: $\mathrm{pH}$, temperature, hardness, nitrate, ammonia, sulphate, turbidity, total dissolved solids, and conductivity were determined using standard methods (Department of Environment, 1972).

The $\mathrm{pH}$ metre was calibrated, using two buffer solutions (buffer $\mathrm{pH} 4$ and buffer $\mathrm{pH}$ 9). The instrument was inserted in the Water samples and reads taken after stability was attained. Temperatures of samples were taken in the field using a mercury filled thermometer.

Hardness was determined by EDTA titration. Nitrate was determined by Phenoldisulphonic acid method, while ammonia concentrations were determined by direct nesslerization method. Sulphate was determined by turbidimetric method (US-EPA, 1983).

\subsection{Turbidity}

Nephelometric method of turbidity determination is based on a comparison of the intensity of light scattered by a sample under defined conditions with the intensity of that under the same condition (APHA-AWWA-WPCF, 1985, p133-140). A Hatch turbidmeter, Model 2100A was used. Turbidimeter was set at zero with distilled water. Samples were thoroughly shaken and a portion poured into sample tubes, making sure no air bubbles were trapped. Sample tubes were thoroughly wiped dried then inserted into the instrument and readings made. Calibration curves were used to determine turbidities of the samples and to calibrate the instrument.

Total Dissolved Solids (TDS) was determined by evaporating an already weighed at 103-105 ${ }^{\circ} \mathrm{C}$ and the difference in weight calculated. Conductivity was determined using a conductivity meter with model number WPA CMD 400 .

\section{Result and Discussion}

Results of water temperature determination indicates the mean values per sample points for Ring road and Orita-Aperin were $28.00{ }^{\circ} \mathrm{C}$ and $27.40{ }^{\circ} \mathrm{C}$, respectively, while that of Agbowo control were $27.00{ }^{\circ} \mathrm{C}$ (Tables 1, 2, and 3). The mean monthly values of same for Ring road, Orita-Aperin and the Agbowo control was observed to be $28.10{ }^{\circ} \mathrm{C}, 27.40{ }^{\circ} \mathrm{C}$ and $27.40{ }^{\circ} \mathrm{C}$, respectively (Tables 4,5 , and 6). There was generally nothing unusual about the temperature values of both dumps and control sites. The results compared favourably with those obtained by Ajayi and Adeleye (1977). The highest temperature was recorded in December and May for Ring road and Orita-Aperin dumpsites. Agbowo surface water showed a fairly lower temperature in both sampling point and mean monthly values than Oniyere and Onikoko streams of Orita-Aperin and Ring road dumpsites, respectively.

The mean $\mathrm{pH}$ values obtained from the study areas (Ring road and Orita-Aperin) and Agbowo control area were all within the generally acceptable range. There was no significant difference in $\mathrm{pH}$ values between the upstream and downstream sampling points.

(Tables 1 to 3). Generally, the $\mathrm{pH}$ was found to be between neutral to slightly alkaline, especially for Agbowo control area for both sampling points and mean monthly values. The alkaline nature of Agbowo surface water may have a lot to do with the way through which the stream has been illegally turned into disposal site, especially in absence of such a facility within the area.

The observed mean values for hardness were below WHO maximum permissible limit of $500 \mathrm{mgCaCO}_{3} \cdot \mathrm{L}^{-1}$. The total hardness per sampling point from Agbowo was $229 \mathrm{mgCaCO}_{3} \cdot \mathrm{L}^{-1}$, while mean monthly values was 233 $\mathrm{mgCaCO} \cdot \mathrm{L}^{-1}$ which represents a fairly hard situation.

The nitrate content of both the study and control areas were found to be below the WHO highest desirable level and the Nigerian Federal Environmental Protection Agency limit of $45 \mathrm{mg} \cdot \mathrm{L}^{-1}$ and $50-100 \mathrm{mg} \cdot \mathrm{L}^{-1}$, respectively (WHO, 1993; FEPA, 1992). The highest value for the surface water was recorded in the August, while the lowest was in 
May (Tables 4, 5, and 6). The high nitrate of levels in surface water in August may be due to wash-off of nitrate containing matter from the surrounding areas into the streams during rainfall. Quality parameters of urban water sources do not, however, always vary with seasonal changes, rather the changes are dictated by human activities or land use. Higher nitrate in surface water samples from Agbowo control area may be due to pollution of these sources from sewage matter and from wastes that inadvertently find their ways into the steam.

The mean ammonia contents of surface water from Agbowo control area was higher than those of Ring road and Orita-Aperin, due to the same reasons as explained for nitrate above, that is, sewage and house hold waste disposal. Despite the seemingly varied mean ammonia levels among the surface waters of the three areas investigated, it was established statistically that the mean values were not significantly different (at $\alpha=0.05$ ), confirming none serious impaction of solid waste disposal on the surface water with respect to nitrate.

Sulphate levels of surface water samples from dumpsites and control area were found to be quite high, but well within safe limit of $250 \mathrm{mg} \cdot \mathrm{L}^{-1}$, stipulated by the United States Public Health Service (USPHS), International WHO limit of $400 \mathrm{mg} \cdot \mathrm{L}^{-1}$ and the Nigerian Federal Environmental Protection Agency (FEPA) permissible level of $150 \mathrm{mg} \cdot \mathrm{L}^{-1}$ (FEPA, 199210).

The monthly mean values of sulphate for surface water samples from Agbowo control area was higher than those of the two dump study areas, with the highest and lowest values recorded in October and September, respectively (Tables 4, 5, and 6). High sulphate in Agbowo water samples can equally be in line with the other parameters discussed earlier.

Surface water samples of Ring road dumpsite were the most turbidity followed by those of Orita-Aperin, then Agbowo control area (Tables 1, 2, and 3). Surface waters of Ring road were on average most turbidity in the month of August and least so in the month of September. In Agbowo the highest turbidity value was equally recorded in the month of August while the lowest was in the month of November. For streams and other surface waters, human activities and/or land-use appear to be the most important factor(s) that determine turbidity. Seasonal changes may also be important. As would be expected, the upstream sampling points are less turbidity than the downstream points, especially for Ring road and Agbowo areas. This suggests that the origin of turbidity-causing materials is at a point between upstream and downstream sampling points. This could probably be linked to the wastes from the dumpsites.

The Total dissolved solids (TDS) in Agbowo surface water samples were found to be higher than those of Ring road and Orita-Aperin study areas/dumpsites (Tables 1,2 and 3). The results also indicate highest and lowest mean monthly TDS in August and November for Ring road surface water. In the case of Orita-Aperin, the highest and lowest were obtained in September and June. High TDS values obtained in August may be as a result of heavy rains and flooding in August as compared to the lower values obtained in November. It may also be as result of direct dumping of waste into the stream among other consequences. Large amount of TDS in water is a confirmation of pollution due especially to solid wastes. Mean values of TDS per sampling point from all areas investigated are far below WHO guidelines and EC admissible levels, both of which have a maximum limit of $1500 \mathrm{mg} \cdot \mathrm{L}^{-1}$ (De Zuane, 1990). The highest conductivity value of $134.00 \mathrm{mS} \cdot \mathrm{m}^{-2} \cdot \mathrm{mol}^{-1}$ was recorded from Agbowo control area followed by Orita-Aperin with a mean monthly value of $105.00 \mathrm{mS} \cdot \mathrm{m}^{-2} \cdot \mathrm{mol}^{-1}$. Ring road has the lowest value of $41.00 \mathrm{mS} \cdot \mathrm{m}^{-2} \cdot \mathrm{mol}^{-1}$ (Tables $4,5,6$ ). The conductivity values by sampling points also correlate with Agbowo control area having the highest value followed by Orita-Aperin, then Ring road (Tables 1, 2, 3). Conductivity of water is a useful test for quick determination of the level of mineralization of both raw and treated waters (Suelgrove, 1980). If properly carried out it correlates well with TDS values.

\section{Conclusion}

Results of the study showed that all water quality parameters were within the limits regulated by WHO and FEPA, except that turbidity was relatively high. It is believed that continuous pollution of the water sources by the dumpsites might led to the accumulation of the pollutants in these water sources, which might result to some health threat both to humans and animals. The continuous accumulation of these pollutants may thwart the use of these water sources for many applications.

\section{References}

Ajayi, S. O., \& Adelaye, S. A. (1977). Pollution studies on Nigerian rivers I. Preliminary report on the pollution level of river Ona and Ogunpa. Bulletin of the Chemical Society of Nigeri, 2, 71-85.

Akintola, F. O., \& Nyamahy, N. C. (1978). Land use and surface water pollution in Ibandan: In Oguntoyinbo, J, S.et al. (Eds). Resources and development in Nigeria. Vol. III, Federal surveys, Lagos.

De Zuane, J. (1990). Handbook of drinking water Quality, Standards and controls. Van Nostrand ReinHold, New 
York. p532.

Department of Environment. (1972). Analysis of raw, portable and wastewater, Her Majesty's stationary office, London, 305p.

Douglas, E., \& Jackson, D. V. (1972). Waste as a material. Journal of Soc. Environ. Engineers, June No. 58, $10-14$.

FEPA. (1992). Guidelines and standards for environmental protection in Nigeria, FEPA, Abuja. 238p.

Hughes,G. M., London, R. A., \& Farvolden, R. N. (1971). Hydrology of waste disposal site in North Eastern Illinois; US-EPA, Washington DC 154p.

Jorgenson, E., \& Johnson, I. (1989). Principles of environmental science and technology (Studies in environmental science 33). Elsevier, Amsterdam. 627p.

Korte, F., \& Bienkiek, D. (1987). Incineration of waste-A solution to a present-day problem, In Abbou, R. (Ed.) Hazardous waste: Detection, control and treatment, part B. Proc. World conference on hazardous waste, Budapest, Hungary, October, 23-31, June No 58, 10-14.

Suelgrove, F. B. (1980). Electromagnetic mapping of ground water contaminants. Water Science and Technology, $18,153-154$.

US-EPA. (1971). Guidelines for local government on solid waste management; Public health series publication. No. 208A, US-EPA, Washington DC 183.

WHO. (1993). World Health Organization's International Standards for drinking water. 158p.

Table 1. Surface water quality by sampling points around Orita - Aperin dumpsite from June 2004 to May 2005

\begin{tabular}{|c|c|c|c|c|c|c|c|c|c|}
\hline & Temperature Turbidity & TDS & Conductivity & $\mathrm{pH}$ & Hardness & $\mathrm{NO}_{3}^{-}$ & $\mathrm{SO}_{4}^{2-}$ & $\mathrm{NH}_{3}$ \\
\hline & ${ }^{\circ} \mathrm{C}$ & $(\mathrm{FTU})$ & $(\mathrm{mg} / \mathrm{L})$ & $\left(\mathrm{mS} / \mathrm{m}^{2} \mathrm{~mol}^{-1}\right)$ & & $\left(\mathrm{mgCaCO}_{3} / \mathrm{L}\right)$ & $(\mathrm{mg} / \mathrm{L})$ & $(\mathrm{mg} / \mathrm{L})$ & $(\mathrm{mg} / \mathrm{L})$ \\
\hline Upstream & $27.70 \pm 1.60341 \pm 38$ & $400 \pm 29$ & $58 \pm 5$ & $7.50 \pm 0.10$ & $146 \pm 7$ & $12.30 \pm 1.00$ & $15.90 \pm 2.600 .19 \pm 0.05$ \\
\hline $\begin{array}{c}\text { Down } \\
\text { Stream }\end{array}$ & $27.00 \pm 1.20165 \pm 32$ & $910 \pm 68$ & $143 \pm 11$ & $7.60 \pm 0.30$ & $176 \pm 8$ & $14.80 \pm 2.10$ & $3.70 \pm 0.40$ & $0.45 \pm 0.16$ \\
\hline Mean & $27.40 \pm 0.14253 \pm 34655 \pm 49$ & $104 \pm 8$ & $7.60 \pm 0.20$ & $161 \pm 8$ & $13.55 \pm 1.60$ & $9.80 \pm 2.50$ & $0.32 \pm 0.32$ \\
\hline
\end{tabular}

Table 2. Surface water quality by sampling points around Ring road dumpsite from June 2004 to May 2005

\begin{tabular}{|c|c|c|c|c|c|c|c|c|c|}
\hline & Temperature & Turbidity & TDS & Conductivity & $\mathrm{pH}$ & Hardness & $\mathrm{NO}_{3}^{-}$ & $\mathrm{SO}_{4}^{2-}$ & $\mathrm{NH}_{3}$ \\
\hline & ${ }^{\circ} \mathrm{C}$ & $(\mathrm{FTU})$ & $(\mathrm{mg} / \mathrm{L})$ & $\left(\mathrm{mS} / \mathrm{m}^{2} \mathrm{~mol}^{-1}\right)$ & & $\left(\mathrm{mgCaCO}_{3} / \mathrm{L}\right)$ & $(\mathrm{mg} / \mathrm{L})$ & $(\mathrm{mg} / \mathrm{L})$ & $(\mathrm{mg} / \mathrm{L})$ \\
\hline Upstream & $28.50 \pm 0.60$ & $161 \pm 28$ & $180 \pm 35$ & $16 \pm 2$ & $6.90 \pm 0.40$ & $29 \pm 5$ & $8.88 \pm 2.1$ & $6.70 \pm 0.80$ & $0.04 \pm 0.10$ \\
\hline Down Stream & $7.50 \pm 1.20$ & $700 \pm 151$ & $550 \pm 13$ & $77 \pm 13$ & $7.40 \pm 0.2$ & $145 \pm 11$ & $14.00 \pm 2.1$ & $7.70 \pm 1.30$ & $0.20 \pm 0.80$ \\
\hline Mean & $28.00 \pm 0.80$ & $431 \pm 9$ & $365 \pm 53$ & $47 \pm 7$ & $7.20 \pm 0.20$ & $87 \pm 80$ & $11.44 \pm 2.1$ & $7.20 \pm 1.00$ & $0.12 \pm 0.50$ \\
\hline
\end{tabular}

Table 3. Surface water quality by sampling points around Agbowo control area from June 2004 to May 2005

\begin{tabular}{|c|c|c|c|c|c|c|c|c|c|}
\hline & Temperature & Turbidity & TDS & Conductivity & $\mathrm{pH}$ & Hardness & $\mathrm{NO}_{3}^{-}$ & $\mathrm{SO}_{4}^{2-}$ & $\mathrm{NH}_{3}$ \\
\hline & ${ }^{\circ} \mathrm{C}$ & $(\mathrm{FTU})$ & $(\mathrm{mg} / \mathrm{L})$ & $\left(\mathrm{mS} / \mathrm{m}^{2} \mathrm{~mol}^{-1}\right)$ & & $\left(\mathrm{mgCaCO}_{3} / \mathrm{L}\right)$ & $(\mathrm{mg} / \mathrm{L})$ & $(\mathrm{mg} / \mathrm{L})$ & $(\mathrm{mg} / \mathrm{L})$ \\
\hline Upstream & $27.30 \pm 1.0$ & $79 \pm 26$ & $820 \pm 145$ & $114 \pm 11$ & $7.80 \pm 0.40$ & $199 \pm 70$ & $28.30 \pm 0.71$ & $19.80 \pm 0.380 .44 \pm 0.13$ \\
\hline $\begin{array}{c}\text { Down } \\
\text { Stream }\end{array}$ & $26.60 \pm 1.0$ & $189 \pm 45$ & $780 \pm 115$ & $149 \pm 0.54$ & $8.00 \pm 0.40$ & $259 \pm 14$ & $11.00 \pm 0.25$ & $17.62 \pm 0.300 .29 \pm 0.25$ \\
\hline Mean & $27.00 \pm 1.0$ & $134 \pm 37$ & $800 \pm 130$ & $132 \pm 33$ & $7.90 \pm 0.40$ & $229 \pm 16$ & $19.65 \pm 0.43$ & $18.71 \pm 0.340 .65 \pm 0.20$ \\
\hline
\end{tabular}


Table 4. Surface water quality around Ring road dumpsite from June 2004 to May 2005

\begin{tabular}{|c|c|c|c|c|c|c|c|c|c|}
\hline Month & Temperature & Turbidity & TDS & Conductivity & $\mathrm{pH}$ & Hardness & $\mathrm{NO}_{3}^{-}$ & $\mathrm{SO}_{4}^{2-}$ & $\mathrm{NH}_{3}$ \\
\hline & $\left({ }^{\circ} \mathrm{C}\right)$ & $(\mathrm{FTU})$ & $(\mathrm{mg} / \mathrm{L})$ & $\left(\mathrm{mS} / \mathrm{m}^{2} \mathrm{mo}^{-1}\right)$ & & $\left(\mathrm{mgCaCO}_{3} / \mathrm{L}\right)$ & $(\mathrm{mg} / \mathrm{L})$ & $(\mathrm{mg} / \mathrm{L})$ & $(\mathrm{mg} / \mathrm{L})$ \\
\hline June & 27.30 & 533 & 250 & 54 & 7.20 & 91 & 12.42 & 7.13 & 0.12 \\
\hline July & 27.80 & 452 & 384 & 54 & 7.30 & 76 & 10.08 & 8.08 & 0.13 \\
\hline August & 28.00 & 750 & 640 & 15 & 7.20 & 87 & 15.16 & 7.87 & 0.13 \\
\hline September & 28.60 & 443 & 341 & 47 & 7.30 & 136 & 12.21 & 6.58 & 0.18 \\
\hline October & 28.40 & 430 & 350 & 40 & 7.30 & 90 & 10.81 & 7.42 & 0.17 \\
\hline November & 28.50 & 136 & 160 & 14 & 7.50 & 25 & 10.98 & 7.25 & 0.03 \\
\hline December & 28.80 & 351 & 313 & 53 & 6.70 & 88 & 09.83 & 7.76 & 0.17 \\
\hline Jan/Feb. & 28.10 & 368 & 315 & 38 & 7.00 & 84 & 10.07 & 7.01 & 0.07 \\
\hline March & 28.40 & 323 & 331 & 47 & 7.30 & 95 & 12.87 & 6.05 & 0.30 \\
\hline April & 27.70 & 390 & 373 & 55 & 7.00 & 98 & 11.5 & 6.55 & 0.12 \\
\hline May & 27.10 & 575 & 448 & 52 & 7.00 & 81 & 09.15 & 5.14 & 0.03 \\
\hline Mean & $28.10 \pm 0.50432 \pm 160432 \pm 160$ & $41 \pm 15$ & $7.20 \pm 0.02$ & $86 \pm 26$ & $11.40 \pm 0.00$ & $7.20 \pm 0.600 .12 \pm 0.50$ \\
\hline
\end{tabular}

Table 5. Surface water quality around Orita-Aperin dumpsite from June 2004 to May 2005

\begin{tabular}{|c|c|c|c|c|c|c|c|c|c|}
\hline Month & Temperature & Turbidity & TDS & Conductivity & $\mathrm{pH}$ & Hardness & $\mathrm{NO}_{3}^{-}$ & $\mathrm{SO}_{4}^{2-}$ & $\mathrm{NH}_{3}$ \\
\hline & $\left({ }^{\circ} \mathrm{C}\right)$ & $(\mathrm{FTU})$ & $(\mathrm{mg} / \mathrm{L})$ & $\left(\mathrm{mS} / \mathrm{m}^{2} \mathrm{~mol}^{-1}\right)$ & & $\left(\mathrm{mgCaCO}_{3} / \mathrm{L}\right)$ & $(\mathrm{mg} / \mathrm{L})$ & $(\mathrm{mg} / \mathrm{L})$ & $(\mathrm{mg} / \mathrm{L})$ \\
\hline June & 27.60 & 259.50 & 600 & 95 & 7.60 & 154 & 12.13 & 9.66 & 0.33 \\
\hline July & 26.50 & 285.50 & 655 & 108 & 7.60 & 153 & 14.05 & 10.63 & 0.42 \\
\hline August & 27.90 & 272.00 & 660 & 101 & 7.50 & 155 & 14.11 & 9.43 & 0.31 \\
\hline September & 28.60 & 212.00 & 995 & 135 & 7.30 & 162 & 14.19 & 9.00 & 0.28 \\
\hline October & 28.80 & 265.00 & 608 & 111 & 7.50 & 159 & 12.66 & 10.12 & 0.36 \\
\hline November & 27.90 & 230.00 & 695 & 98 & 7.40 & 158 & 12.72 & 9.75 & 0.29 \\
\hline December & 26.40 & 238.00 & 666 & 95 & 7.80 & 172 & 13.48 & 11.69 & 0.21 \\
\hline Jan/Feb. & 26.90 & 226.00 & 718 & 111 & 7.50 & 164 & 12.81 & 11.35 & 0.21 \\
\hline March & 27.80 & 224.00 & 663 & 105 & 7.60 & 164 & 14.16 & 10.91 & 0.25 \\
\hline April & 26.10 & 274.00 & 653 & 99 & 7.80 & 162 & 14.63 & 7.46 & 0.47 \\
\hline May & 28.70 & 232.00 & 693 & 92 & 7.70 & 172 & 14.15 & 7.82 & 0.35 \\
\hline Mean & $27.40 \pm 0.90247 .00 \pm 25692 \pm 107$ & $105 \pm 120$ & $7.20 \pm 0.20$ & $161 \pm 7$ & $13.55 \pm 0.059 .80 \pm 1.340 .32 \pm 0.08$ \\
\hline
\end{tabular}


Table 6. Surface water quality around Agbowo control area from June 2004 to May 2005

\begin{tabular}{|c|c|c|c|c|c|c|c|c|c|}
\hline Month & Temperature & Turbidity & TDS & Conductivity & $\mathrm{pH}$ & Hardness & $\mathrm{NO}_{3}^{-}$ & $\mathrm{SO}_{4}^{2-}$ & $\mathrm{NH}_{3}$ \\
\hline June & 26.60 & 160 & 946 & 153 & 8.00 & 223 & 38.11 & 17.89 & 0.82 \\
\hline July & 27.30 & 165 & 909 & 131 & 8.10 & 226 & 17.20 & 18.09 & 0.78 \\
\hline August & 25.50 & 186 & 781 & 141 & 8.30 & 249 & 8.38 & 13.93 & 0.77 \\
\hline September & 27.00 & 146 & 838 & 149 & 8.40 & 236 & 22.39 & 21.75 & 0.52 \\
\hline October & 27.70 & 115 & 783 & 88 & 7.70 & 222 & 14.21 & 22.05 & 0.79 \\
\hline November & & 50 & 655 & 101 & 7.30 & 208 & 31.41 & 15.52 & 0.35 \\
\hline December & 27.60 & 93 & 615 & 89 & 7.90 & 224 & 17.65 & 17.98 & 1.06 \\
\hline Jan/Feb. & 26.80 & 83 & 735 & 189 & 8.20 & 232 & 13.69 & 21.10 & 0.35 \\
\hline March & 27.00 & 116 & 710 & 101 & 8.00 & 274 & 21.77 & 19.33 & 0.64 \\
\hline April & 26.26 & 163 & 748 & 155 & 7.60 & 232 & 21.65 & 20.33 & 0.53 \\
\hline May & 25.60 & 183 & 968 & 178 & 7.50 & 232 & 23.75 & 14.71 & 0.74 \\
\hline Mean $27.40 \pm 0.90$ & $133 \pm 0.44189 \pm 1.14$ & $134 \pm 35$ & $7.90 \pm 0.30$ & $233 \pm 170$ & $20.93 \pm 8.3018 .43 \pm 2.810 .67 \pm 0.22$ \\
\hline
\end{tabular}

